\title{
Freshwater crabs occupying tropical north Queensland coastal creeks
}

\author{
Nathan J. Waltham', Jane M. Hughes ${ }^{2}$, Peter J. F. Davie ${ }^{3}$
}

'Centre for Tropical Water and Aquatic Ecosystem Research (TropWATER), James Cook University, Townsville Campus, Queensland, 48I I, Australia

${ }^{2}$ Australian Rivers Institute, School of Environment, Griffith University, Queensland, 4III, Australia

${ }^{3}$ Queensland Museum and Sciencentre, PO Box 3300, South Brisbane, Queensland, 4101 , Australia

${ }^{*}$ Corresponding Author Tel + 6I 7478 4191; fax + 61 747815589

E-mail address: nathan.waltham@jcu.edu.au

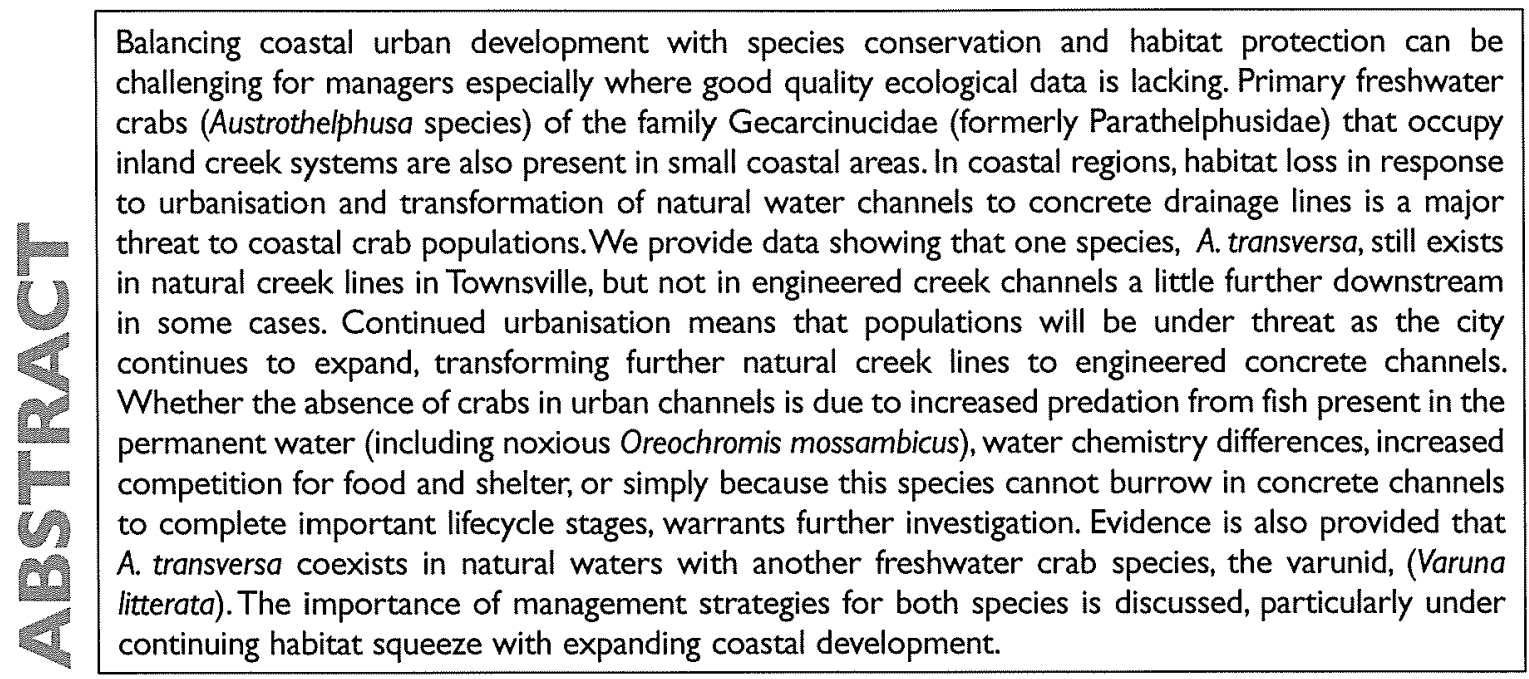

Key words: biodiversity, freshwater crabs, urbanisation, stormwater channels, Townsville, Austrothelphuso transversa, Varuna litterata, coastal squeeze

DOl: http://dx.doi.org/I0.7882/AZ.2014.005

\section{Introduction}

Balancing conservation and biodiversity outcomes with ever increasing urban development is a major challenge facing managers across the world. Urbanisation of the coastal zone directly affects key marine wetland habitats such as mangroves and saltmarsh (Lee et al. 2006; Grimm et al. 2008; Waltham and Connolly 2011). The greatest threats to freshwater biodiversity are habitat destruction, poor water quality, introduced species, agricultural development, reservoir barriers, and climate change leading to reduction in flow conditions (Dudgeon et al. 2006). Such impacts on freshwater creeks and coastal wetlands can, in turn, negatively influence coastal marine fisheries production (Burrows et al. 2009; Pearson et al. 2013).

Coastal north Queensland habitats are not only subject to many of the normal impacts associated with the squeeze from coastal development and urbanisation already mentioned, but are also increasingly subjected to the effects of expanding mining operations, and alterations to river flow from both anthropogenic and natural causes. Thus, continued protection of tropical freshwater ecosystems will be challenging, and management responses are likely to be expensive (Swan and Wilson 2012). A major first step in urban ecological research is to understand the structure and dependencies of the local communities, as well as the life cycle requirements of at least key local species, prior to proposed development. Secondly, knowledge about ecological processes is necessary and this requires data commitment to ecological monitoring, to establish baseline conditions and after development to measure extent of change. A management scheme can only be truly effective if it is developed using a holistic approach that integrates good ecological understanding into the process of urban approval and planning (Niemela 1999).

Freshwater crabs are found in the tropics and subtropics in most parts of the world (Burggren and McMahon 1988), and are a key component in many tropical freshwater systems. There are more than 7,000 known species of brachyuran crabs ( $\mathrm{Ng}$ et al. 1988), of which approximately 1,300 are primary freshwater crabs (Cumberlidge et al. 2009). Primary freshwater crabs have adopted freshwater, semi-terrestrial or terrestrial modes of life, and complete their lifecycle independent of the sea (Yeo et al. 2008). Most species remain hidden during the day, presumably a response to predation, and forage at night feeding on plant material, but some are opportunistic carnivores or scavengers (Ng 1988; Davie 2012). Many species are highly adapted to deal with the ephemeral nature of creeks, digging holes into channel sides to reach the water 
table where they lay quiescent until wet season flow, up to 6 years in some cases (Davie 2012).

An estimate of global biodiversity of primary freshwater crabs suggests that a large number of species are yet to be described/discovered (Yeo et al. 2008). This conclusion is based on data which calculated expected numbers of species within a unit area and compared to known species numbers within the same region (see Yeo and $\mathrm{Ng}$ 1999). This disparity suggests at least 120 , and as many as 850 more species are yet to be discovered world-wide (Yeo et al. 2008). Cumberlidge et al. (2009) have done a basic conservation assessment of the known species of freshwater crab for the IUCN Red List. They noted that two-thirds of all species may be at risk of going extinct, with one in six species particularly vulnerable, and of those, 227 species should be considered as near threatened, vulnerable, endangered or critically endangered. For about half (628 species), there is still insufficient data to adequately assess their future. In the local context, seven species have been recorded from northern Australia (Davie 2002), though a further 15 to 20 new species remain to be described, most with distributions limited to small coastal catchments (Davie in prep.).

For the few already named Australian species little is known of their ecology, biology and habitat requirements (Davie 2012), although the Inland Freshwater crab, Austrothelphusa transversa (Fig. 1a; von Martens, 1868), is the most widespread and best known species, and it has been the subject of a number of physiological and other studies (e.g., Greenaway and MacMillen 1978; Greenwaway 1980; Greenwaway et al. 1983a, b). Austrothelphusa transversa is found west of the Great Dividing range across most of inland northern Australia from Fitzroy River, near Derby, to west of Chillagoe, north Queensland, and south to the Lake Eyre catchment and down the Murray-Darling system to about Nyngan, mid-western New South Wales. With the exception of a strip east of the Great Dividing Range between Townsville and Gladstone, Queensland, it is typically not found in coastal flowing drainages. This Queensland coastal population is clearly isolated from the inland catchments, and preliminary studies by Davie and Gopurenko (unpublished) suggest that there is some genetic differentiation from the inland populations, and that there may be grounds for recognising a new species

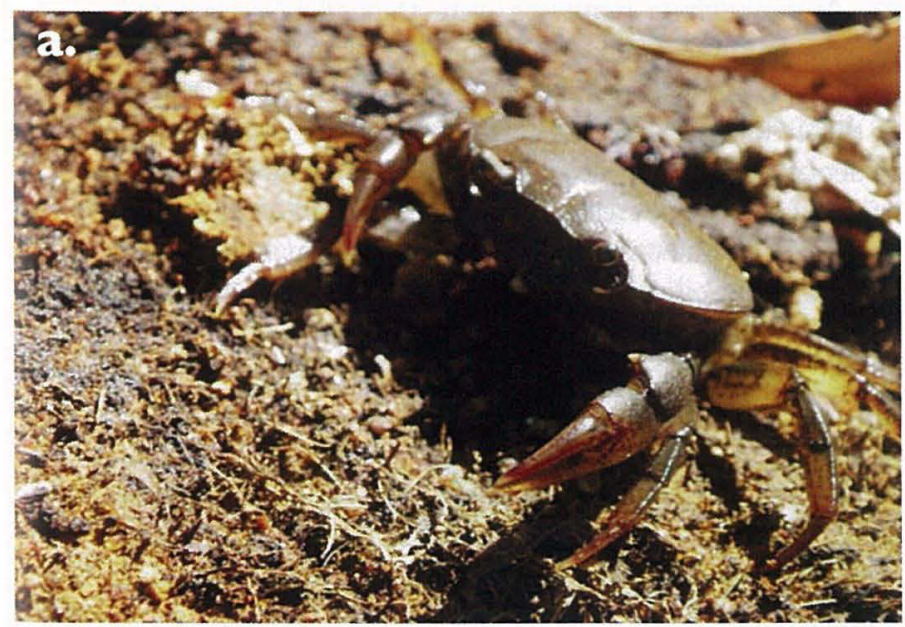

for these Queensland east coast crabs. Reproductively, freshwater crabs are generally K-strategists, with low fecundity, and direct development of eggs carried under the female abdomen right through to the juvenile crab stage that hatch from these eggs. Thus there is little ability for widespread dispersal, and there is likely to be little or no gene flow between separate rivers; particularly across major catchment boundaries, a process common for freshwater crab species elsewhere (Liu and Li 2000).

Urbanisation of coastal areas often leads to the replacement of natural creeks with concrete drains, road crossings, car parks and residential estates, while sometimes waterways simply become filled with sediment (Waltham et al. 2011). In these cases, it is predicted that the survival of local populations of freshwater crabs may be compromised, but unfortunately such crabs tend to be poorly represented in most limnological impact studies (e.g., Environmental Impact Assessments) because they are not easily caught using conventional freshwater sampling techniques such as electrofishing or fishing nets, though invertebrate dip nets can be useful.

The study reported here was designed to investigate whether the presence and abundance of coastal north Queensland populations of Austrothelphusa transversa differed between natural and urban creeks further downstream. It is intended that this study will provide important data to assist resource managers when assessing future urban development proposals.

\section{Methods}

\section{Survey area}

Townsville is an expanding urban city in northern Queensland (Fig. 2). The 2011 population of approximately 187,000 is expected to increase to 250,000 by 2031 (Gunn and Manning 2010). To accommodate the increasing human population, large areas of existing natural and agricultural farming land have been designated for future urban real estate. Urban development contributes to changes in the hydrograph by increasing peak flow intensity compared to forested catchments where rainfall is soaked up by the vegetation (Goonetillek et al. 2005). In an attempt to mitigate residential properties and assets (e.g. roadways,

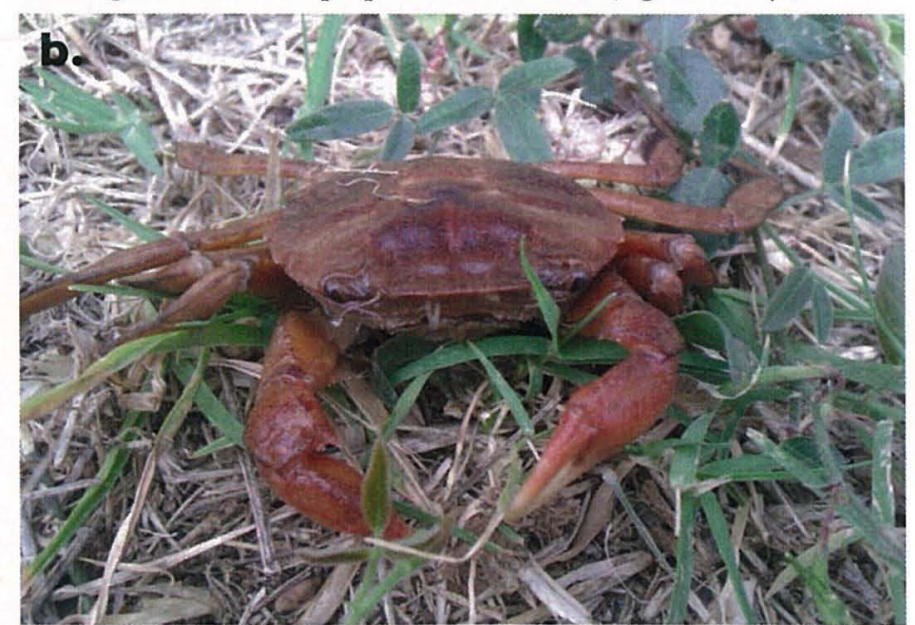

Fig. I. Inland freshwater crab (Austrothelphusa transversa) feeding on an exposed sandy bank in natural habitat in upper reaches of Townsville creeks. River swimming crab (Varuna litterata) captured in natural creek, Bowen, north Queensland. 
bridges) against local flooding, parts of Townsville City are supported by a network of concrete open stormwater drains engineered to rapidly move stormwater runoff away from housing estates and infrastructure to the Ross River and the coastal waters of the Great Barrier Reef lagoon. These concrete water channels are often straight, featureless in terms of habitat and offer limited structure for aquatic fauna to seek shelter and to burrow, though aquatic habitat can be present, until at least maintenance clearing works occur for flood protection of surrounding housing and infrastructure. Even new urban development unfortunately includes this channelisation from previously natural flow paths (Fig. 3).

Freshwater crabs were collected at 11 selected locations in Townsville covering five natural sites and six urban (constructed creek habitat) sites during the four weeks of April 2013 (Fig. 2). Natural sites had mostly intact riparian vegetation, and a creek channel consisting of rocky and sandy loam material, although some evidence of bank undercutting was apparent. In the Townsville area, the natural creeks are known to seasonally dry completely and only refill after rainfall (Fig. 3). Conversely, the urban sites have permanent water due to their engineered basin, concrete linings and support aquatic vegetation, consisting of a combination of native (e.g. waterlily, Nymphaeceae) and exotic aquatic (e.g. salvinia, Salvinia molesta; water hyacinth, Eichhomia crassipes) species. In several cases, the constructed urban sites were located downstream of natural sites (see Fig. 2). As part of a larger genetic study of freshwater crabs in northern Queensland, we had the opportunity to survey freshwater crabs at a second study area at Dingo Beach, $60 \mathrm{~km}$ south of Bowen. At this site, we used the same four baited traps to survey a series of three waterholes over a $100 \mathrm{~m}$ reach with the data pooled to a single natural site (site 6; Fig. 2b); each waterhole was small size $\sim 10 \mathrm{~m}$ length each) along a natural creek that drains to the coast, near the Dingo Beach township, $60 \mathrm{~km}$ south of Bowen. Crab data for this site is included here as a further test for our hypothesis.

\section{Results and discussion}

There were little differences for the measured water quality variables between urban and natural sites (Table 1). Despite this outcome, the measurements were intended to provide a cursory understanding of the water quality conditions at the time of sampling among sites and between urban and natural habitats. Whether in fact differences in water quality conditions are causal in the measured absence of Austrothelphusa transversa at natural sites requires a more comprehensive examination of water quality, with samples also targeting diel and seasonal variations, including contaminants (heavy metals, organics, herbicides) which are known in coastal urban stormwaters (Birch and Taylor 1999; Waltham et al. 2011).

Overall, Austrothelphusa transversa was recorded only at sites located in natural creeks, well above the influence of urban development and engineered creek channels; the exception was site 5 (natural) where no individual was caught (Table 2). Where caught, total numbers were low (a few individuals only), in contrast to similar dry seasonal natural channels of inland central Queensland
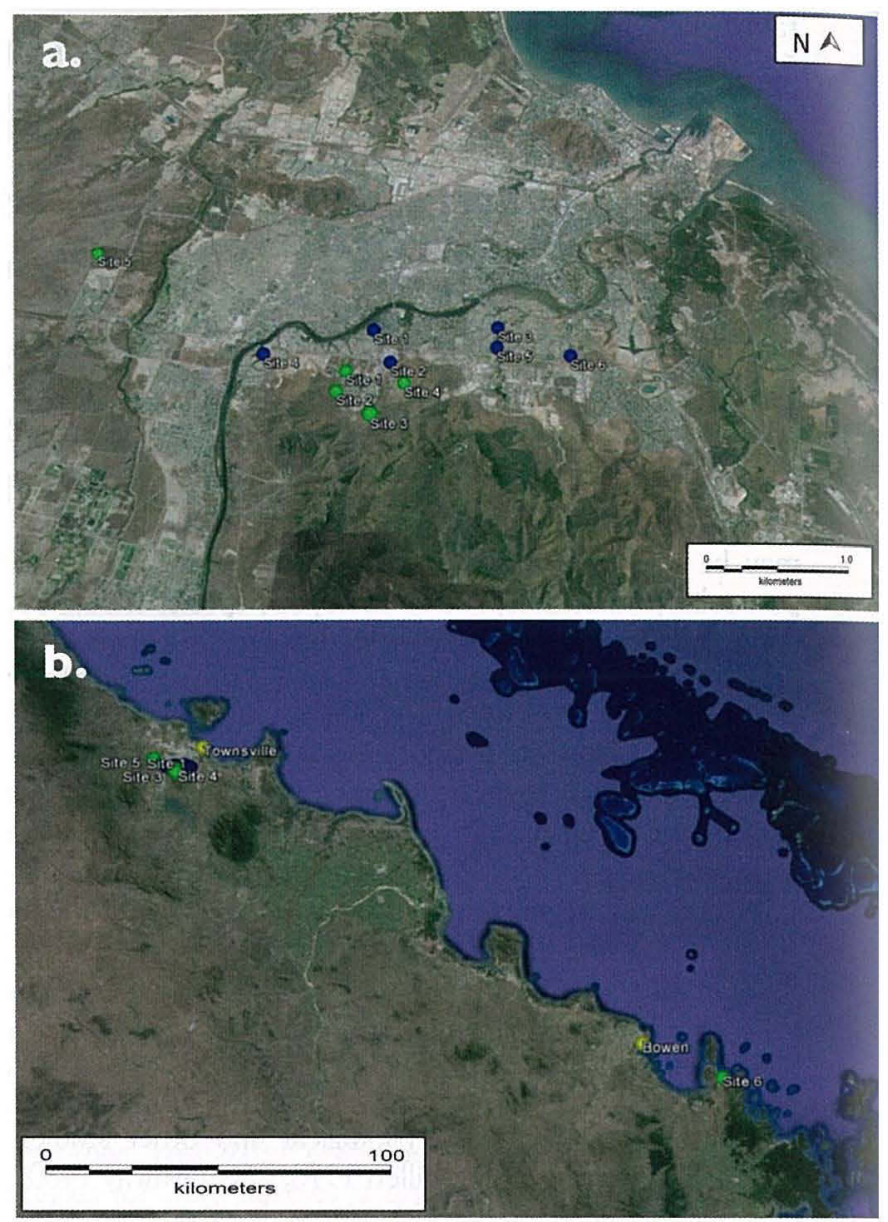

Fig. 2. Location map of sites in: a) Townsville and b) site 6 at Dingo Beach; $40 \mathrm{~km}$ south Bowen, Queensland. Blue, urban; green, natural sites.

where greater (as many as 57 individuals in the same bait traps used here) numbers have been recorded (Waltham unpublished data). The exception was in the small ephemeral creek (site 4 natural) that flows through the campus of the James Cook University, Townsville, where six A. transwersa were captured in a small pool prior to it drying out in May 2013. Although this creek has been subject to minor disturbance with student walkways and footbridges, the creek has retained most of its natural vegetation and channel sediments.

No Austrothelphusa transversa were trapped in engineered waterways immediately $(\sim 500 \mathrm{~m})$ downstream of natural creek sections (Sites 1 and 2). A thorough visual search of these downstream sites found no crab moults, and no evidence of burrows along channel reaches, under rocks, or along the upper creek banks. These urban creeks differ from the natural waterholes by holding permanent water, and are occupied year-round by fish and other crustaceans.

Table I. Average $(n=6 ; S E)$ surface $(0.3 m)$ water quality measurements using calibrated multiprobe (Qanta, Aqualab).

\begin{tabular}{lll} 
Water quality variable & Natural & Urban \\
\hline Temperature $(\mathrm{oC})$ & $28.8(0.65)$ & $28.7(0.77)$ \\
\hline Conductivity $(\mu \mathrm{S} / \mathrm{cm})$ & $548(91.5)$ & $731(158.8)$ \\
\hline Dissolved oxygen $(\%)$ & $63(6.4)$ & $73(13.5)$ \\
\hline $\mathrm{pH}$ & $7.3(0.12)$ & $7.7(0.29)$ \\
\hline
\end{tabular}


Table 2. Crustacean and fish species, total abundance and species richness captured in natural creek and urban sites. Hydrology, $E=$ ephemeral creek, $\mathrm{P}=$ permanent water. $\mathrm{IE}=$ introduced exotic species. $T=$ translocated.

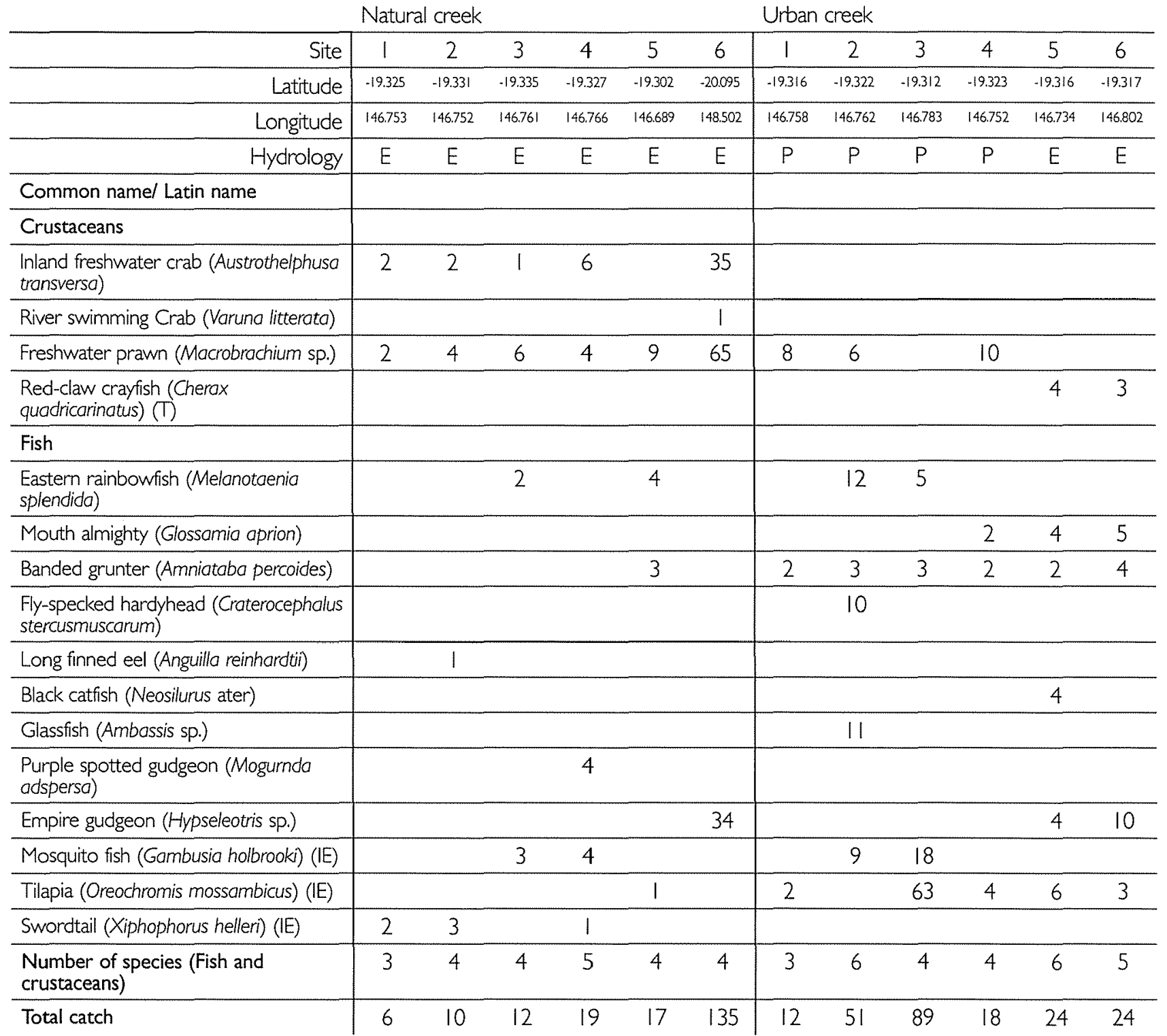

The absence of A. transwersa may be due to differences in some factor/s in the natural compared to engineered water sites. The most obvious differences include increased depth in artificial habitats and the substrate composition whereby crabs cannot burrow into concrete channels compared to natural sediment banks, changes in water flow characteristics and, poorer water quality in urban habitat, or perhaps an increased risk of fish, cane toad (Rhinella marina), bird, lizard and rat predation in urban channels (Waltham personal observations). It is also possible that A. transversa requires a period of drying and estivation as part of its lifecycle, found only in ephemeral natural channels. These are all testable hypotheses that warrant further research.

Fish were a dominant feature of the catch at sites across both habitats (Table 2), particularly tilapia (Oreochromis mossambicus), eastern rainbowfish (Melanotaenia splendida), and empire gudgeon (Hypseleotris sp.). There are some major differences (e.g., mouth almighty; Glossamia aprion, barred grunter; Amniataba percoides, black catfish; Neosilurus ater, and tilapia; O. mossambicus - all predators) which were more predominant in constructed creeks; though a single natural site recorded $O$. mossambicus. Two crustacean species, a freshwater prawn (Macrobrachium sp.) and the red claw crayfish (Cherax quadricarinatus) were also caught. However, this list is not complete as baited traps will only catch a subset of the species present (opening of traps is $5 \mathrm{~cm}$ stretched). A full inventory would require additional survey methods such as seine/cast nets, and electrofishing, and longer term temporal sampling. The use of underwater cameras may also be a useful non-invasive survey tool (Ebner and Morgan 2013). Such a detailed assessment of the entire faunal assemblage would offer insights into interactions between freshwater crabs, fish, and other crustacean species, and would no doubt help to determine whether predation pressure is an important reason for the absence of crabs. Predation selectivity has been previously examined using tilapia (O. mossambicus) in controlled laboratory tank trials (Doupe et al. 2009). In that study, the authors concluded that $O$. mossambicus showed aggression towards many fish species when introduced into tanks and the conclusions were that the presence of invasive species 

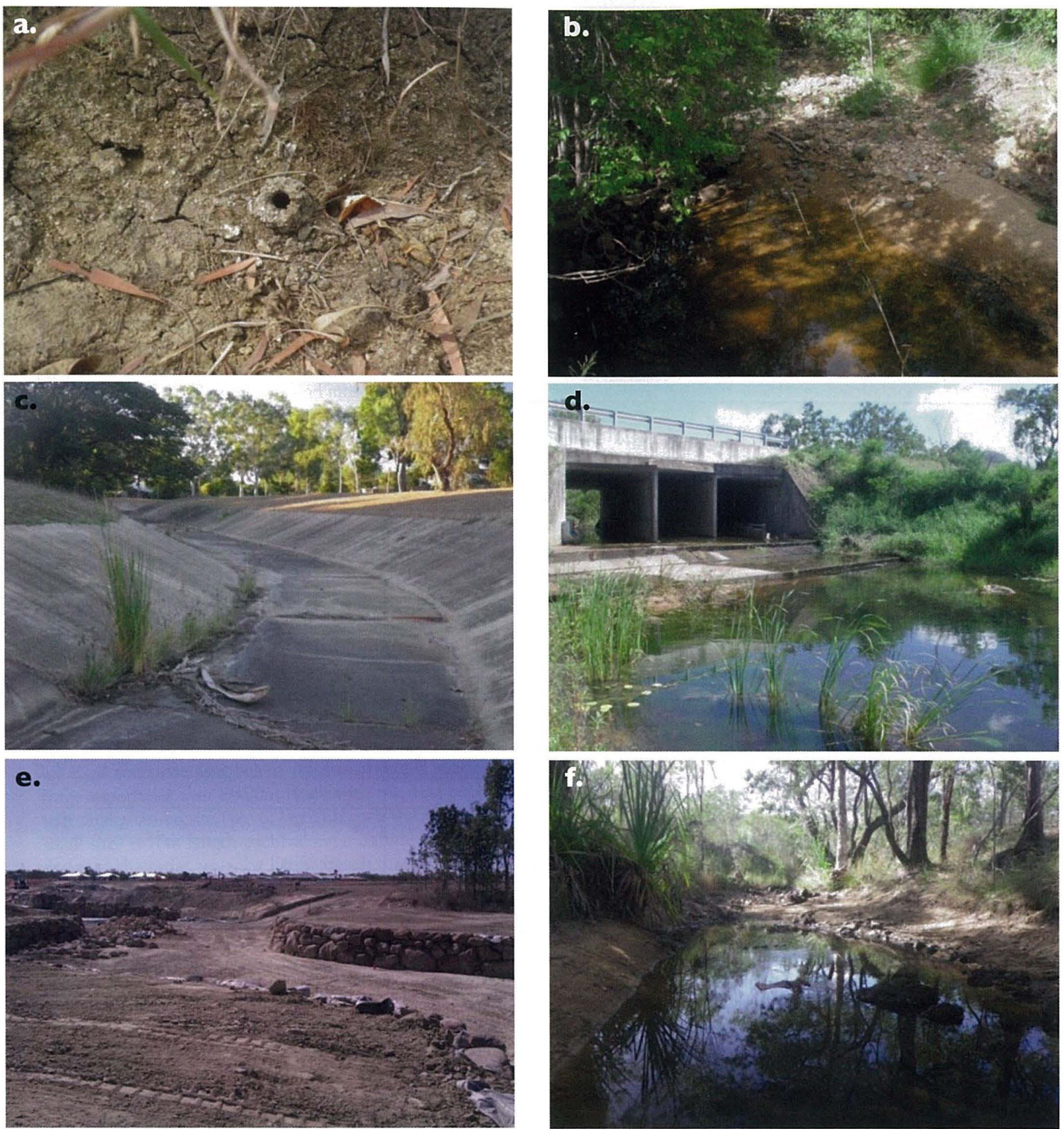

Fig. 3. (a) Example freshwater crab burrow entrance; b) natural habitat pool site located within the campus creek, James Cook University; c) concrete stormwater channel built over natural water course; d) example of pool downstream of concrete stormwater channel that maintains water year round, complete with aquatic plants; e) new residential development in northern Townsville leads to realignment and channalisation of previously natural creek network; and f) natural creek at Dingo Beach.

has the potential to outcompete local fish species. Given the presence of $\mathrm{O}$. mossambicus in most engineered water basins, a similar interaction may also be restricting local freshwater crab distribution. O. mossambicus was caught at a single natural creek site, which was the only natural site where Austrothelphusa transversa was absent, again, supporting the predation model.

At the Dingo Beach site (Fig. 2b) a coastal grapsoid crab, Varuna litterata, was caught in the same waterhole as
Austrothelphusa transversa. Varuna litterata is widespread throughout the Indo-West Pacific (Davie 2002), and is found around subtopical and tropical Australia at least as far south as Brisbane on the east coast. As an adult, it lives in coastal flowing freshwater creeks and water bodies, however, marine larval development is still necessary, with the megalopal stage re-entering estuaries and migrating upstream on an annual basis (see Ryan and Choy 1988). Although relatively uncommonly collected, this may be 
due to its shy and environmentally cryptic nature, so there are no good assessments of its true abundance in tropical creek systems in Australia. However, its persistence across such a wide geographic range suggests that there must be a sufficiently large population available to ensure the species is sustained wherever it occurs (i.e. R strategies). At least one mass recruitment event has been observed in the Adelaide River in the Northern Territory (Davie unpublished). While only a single individual was recorded at the Dingo Beach site, it was caught along with 35 A. transversa individuals in a single bait trap. While V. litterata megalopae are able to emerge from the water for short periods to swarm over minor barriers such as weirs, significant barriers to migration, such as road crossings or complex stormwater networks, could impede migration and survival. This single individual may have been an transient adult as this species is generally found near the sea (e.g., mangrove creeks) and juveniles are found further upstream (Davie personal observations). While V. litterata is more herbivorous/algivorous, though will consume animal material (Devi et al. 2013), A. transversa seems to be more generalist (Waltham personal observations). While this seems to be the first study to record both these species together at the same site, it is possible that both species can easily co-exist, utilising different microhabitats.

Fundamental to successful urban planning is data on the ecological community, habitat requirements and life cycles of the fauna to be affected by any new proposed land development. In many places the coastal catchment is now a multi-use environment consisting of residential, rural, industrial, recreational, water supply, conservation, biodiversity and natural amenity (Lee et al. 2006; Grimm et al. 2008; Waltham and Connolly 2013). Such fabricated landscapes lead to a mix of land uses that are generally constructed independent of each other, and thus do not adequately take into account an outcome of habitat connectivity or specific requirements for local aquatic (Waltham and Sheaves In review). Restoration and repair efforts are underway in many places, in an attempt to build a continuum of habitat connectivity between freshwater and coastal marine areas (Brooks and Lake 2007). Though success in species protection requires data on the lifecycle and habitat requirement dependencies (Harris and Heathwaite 2012), though such data is not yet available for freshwater crabs in Australia.

In terrestrial ecosystems, major negative consequences exist from urbanisation (Hodgkison et al. 2007; Kazemi et al. 2011). The most widely reported is species homogenisation, which occurs as a result of the loss of native flora and fauna, and the gain of non-native species (e.g., exotic gardens), or a community that is similar to the next region: "the anthropogenic blender effect" (sensu stricto Olden 2006). For Townsville, a major concern of continued urban development is increased delivery of pollutants, such as nutrients, sediments, heavy metals and pesticides to downstream estuaries and the Great Barrier Reef Lagoon (Brodie et al. 2011). While treatment of urban stormwater is important for the overall conservation and protection of the Great Barrier Reef, designs to treat stormwater (e.g., urban water sensitive design; Healthy Waterways Strategy 2007) are not typically able to also achieve habitat requirements of local freshwater fauna species at all life stages. Urban stormwater management systems are designed either for achieving water quality outcomes, or biodiversity outcomes, but not both (Healthy Waterways Strategy 2007). Expansion of Townsville over the next few decades is projected to include major new engineered infrastructure such as roadways, car parks, industrial areas, recreational parks and sporting fields, along with residential urban development (Gunn and Manning 2010). Whether this coastal squeeze on available freshwater habitat extends more broadly to other north Queensland City centres (e.g., Cairns, Bowen, Mackay, Rockhampton) is unknown (but probably likely). Balancing urban planning designs with conservation and species protection outcomes will be challenging and requires a partnership arrangement among industry, community, government and scientists.

\section{Acknowledgements}

D. Burrows provided useful comments and input to this study. Sampling equipment was provided by TropWATER (Centre for Tropical Water and Aquatic
Ecosystem Research), James Cook University. The GU/ JCU collaboration grant scheme awarded to NW and JH supported this work.

\section{References}

Birch, G., Taylor, S. 1999. Source of heavy metals in sediments of the Port Jackson estuary, Australia. The Science of the Total Environment 227: 123-138. http://dx.doi.org/10.1016/S0048$9697(99) 00007-8$

Brodie, J. E., Devlin, M., Haynes, D., Waterhouse, J. 2011. Assessment of the eutrophication status of the Great Barrier Reef Lagoon (Australia). Biogeochemistry 106: 281-302. http://dx.doi.org $/ 10.1007 / \mathrm{s} 10533-010-9542-2$

Brooks, S. S., Lake, P. S. 2007. River restoration in Victoria, Australia: change is in the wind and none too soon. Restoration Ecology 15: 584-591. http://dx.doi: 10.1111/j.1526. 100X.2007.00253.x

Burggren, W.W., McMahon, B. R. 1988. Biology of the land crabs, Melbourne, Australia, Cambridge University Press.

Burrows, D., Perna, C., Davis, A. 2009. An assessment of fish passage and connectivity to Gladys Lagoon, Burdekin Floodplain, north Queensland. Townsville: Australian Centre for Tropical Freshwater Research, James Cook University.

Cumberlidge, N., Ng, P.K.L., Yeo, C.J., Magalhaes, C., Campos, M.R., Alvarez, F, Naruse, T., Daniels, S.R., Esser, L.J., Artipoe, F.Y.K. 2009. Freshwater crabs and the biodiversity crisis: Importance, threats, status, and conservation challenges. Biological Conservation 142: 1665-1673. http://dx.doi.org/10.1016/j. biocon.2009.02.038

Davie, P.J.F. 2002. Crustacea: Malacostraca: Eucarida (Part 2: Anomura, Brachyura). In, Wells, A. \& Houston, W.W.K. (Eds) Zoological Catalogue of Australia. Vol, 19.3b. CSIRO Publishing, Melboume. $641 \mathrm{pp}$. 
Davie, PJ.F. 2012. Decapods. Pp. 40-45. In, Curtis, L.K., Dennis, A.J., McDonald, K.M., Kyne, P.M. \& Debus, S.J.S. (Eds), Queensland's Threatened Animals. (CSIRO Publishing: Melbourne). 449 pp.

Devi, P. L., Nair, D. G., Joseph, A. 2013. Habitat ecology and food and feeding of the herring bow crab Varuna litterata (Fabricius, 1798) of Cochin backwaters, Kerala, India. Anthropods 2: 172-188.

Doupe, R. G., Knott, M. J., Schaffer, J., Burrows, D. W. 2009. Investigational piscivory of some juvenile Australian freshwater fishes by the introduced Mozambique tilapia Oreochromis mossambicus. Joumal of Fish Biology 74: 2386-400. http://dx.doi. org/10.1111/j.1095-8649.2009.02254.x

Dudgeon, D., Arthington, A. H., Gessner, M. O., Kawabata, Z, Knowler, D. J., Leveque, C., Naiman, R. J., PrieurRichard, A. H., Soto, D., Stiassny, M. L., Sullivan, C. A. 2006. Freshwater biodiversity: importance, threats, status and conservation challenges. Biological Reviews 81: 163-182. http:// dx.doi.org /10.1017/S1464793105006950

Ebner, B. C., Morgan, D. L., 2013. Using remote underwater video to estimate freshwater fish species richness. Joumal of Fish Biology 82: 1592-1612. http://dx.doi.org/10.1111/jfb.12096

Greenaway, P. 1980. Water balance and urine production in the Australian arid-zone crab, Holthuisana transversa. Joumal of Experimental Biology 87: 237-46.

Greenaway, P., Bonaventura, J., Taylor, H.H. 1983a. Aquatic gas exchange in the freshwater/land crab Holthuisana transversa. Joumal of Experimental Biology 103: 225-236.

Greenaway, P., MacMillen, R.E. 1978. Salt water balance in the terrestrial phase of the inland crab Holthuisana (Austrothelphusa) transversa Martens (Parathelphusoidea: Sundathelphusidae). Physiological Zoology 51: 217-229.

Greenaway, P., Taylor, H.H., Bonaventura, J. 1983b Aerial gas exchange in Australian freshwater/land crabs of the genus Holthuisana. Joumal of Experimental Biology 103: 237-251.

Goonetillek, A., Thomas, E., Ginn, S., Gilbert, D. 2005. Understanding the role of land use in urban stormwater quality management. Journal of Environmental Management 74: $31-42$. http://dx.doi.org/10.1016/j.jenvman.2004.08.006

Grimm, N.B., Faeth, S.H., Golubiewski, N.E., Redman, C.L., Wu, J., Bai, X., Griggs, J.M., 2008. Global change and the ecology of cities. Science 319: 756-760. http://dx.doi.org/10.1126/ science. 1150195

Gunn, J., Manning, C. 2010, Black Ross (Townsville) Water Quality Improvement Plan: Improving Water Quality from Creek to Coral, Townsville City Council - Creek to Coral, Townsville.

Harris, G.P, Heathwaite, A. L. 2012. Why is achieving good ecological outcomes in rivers so difficult? Freshwater Biology 57: 91-107. http://dx.doi DOI: 10.1111/j.1365. 2427.2011.02640.x

Healthy Waterways Partnership 2007. South east Queensland Healthy Waterways Strategy 2007-2012. South East Queensland Healthy Waterways Partnership. Brisbane.

Hodgkison, S. C., Hero, M. J., Warnken, J. 2007. The conservation value of suburban golf courses in a rapidly urbanising region of Australia. Landscape and Urban Planning 79: 323-337. http://dx.doi.org/10.1016/j.landurbplan.2006.03.009
Kazemi, F, Beecham, S., Gibbs, J. 2011. Streetscape biodiversity and the role of bioretention swales in an Australian urban environment. Landscape and Urban Planning 101: 139-148. http://dx.doi.org/10.1016/j.landurbplan.2011.02.006

Lee, S. Y., Dunn, R. J. K., Young, R. A., Connolly, R. M., Dale, P. E. R., Dehayr, R., Lemckert, C.J., McKinnon, S., Powell, B., Teasdale, P.R., Welsh, D. T. 2006. Impact of urbanisation on coastal wetland structure and function. Austral Ecology 31: 149. 163. http://dx.doi.org/10.1111/j.1442-9993.2006.01581.x

Liu, H.G, Li, C.W. 2000. Reproduction in the fresh-water crab Candidiopotamon rathbunae (Brachhura: Potomidae) in Taiwan. Joumal of Crustacean Biology 20: 89-99. http://dx.doi. org/10.1651/0278-0372 (2000)020[0089:RITFWC]2.0.CO;2

Niemela, J. 1999. Ecology and urban planning. Biodiversity and Conservation 8: 119-131. http://dx.doi. org/10.1023/A:1008817325994

Ng, P.K.L. 1988. The freshwater crabs of Peninsular Malaysia and Singapore. Department of Zoology, National University of Singapore, Shinglee Press, Singapore.

Olden, J. D. 2006. Biotic homogenization: a new research agenda for conservation biogeography. Joumal of Biogeography 33: 2027 2039. http://dx.doi.org/10.1111/j.1365-2699.2006.01572.x

Pearson, R. G., Godfrey, P. C., Arthington, A. H., Wallace, J., Karim, F., Ellison, M., 2013. Biophysical status of remnant freshwater floodplain lagoons in the Great Barrier Reef catchment: a challenge for assessment and monitoring. Marine and Freshwater Research 64: 208-222. http://dx.doi.org/10.1071/MF12251

Ryan, P.A, Choy, S. A., 1990. Observations on the mass upstream migration of Varuna litterata (Fabricius) Megalopae (Decapoda, Brachyura, Grapsidae) in Fiji. Crustaceana 58: 237-249.

Swan, G., Wilson, S. 2012. The results of fauna recovery from gas pipeline trench, and a comparison with previously published reports. Australian Zoology 36: 29-36. http://dx.doi.org /10.7882/ AZ.2012.028

Waltham, N.J., Connolly, R.M. 2011. Global distribution and extent of artificial urban waterways. Estuarine and Coastal Shelf Science 94: 192-197. http://dx.doi.org/10.1016/j.ecss.2011.06.003

Waltham, N. J., Teasdale, P. R., Connolly, R. M. 2011. Contaminants in water, sediment and fish from natural and artificial residential waterways in southern Moreton Bay. Joumal of Environmental Monitoring 13: 3409-3419. http://dx.doi.10.1039/ C1EM10664C

Waltham, N.J., Connolly, R.M. 2013. Artificial urban lakes: built for humans, home for fish. Ecological Engineering 60: 414- 420. http://dx.doi.org/10.1016/j.ecoleng.2013.09.035

Yeo, D.C.J., Ng., P.K.L. 1999. The state of freshwater crab taxonomy in Indochina (Decapoda, Brachyura). In: Schram, F. R. and J. C. von Vaupel Klein (eds.), Crustaceans and the Biodiversity Crisis, Proceedings of the Fourth International Crustacean Congress, Amsterdam, The Netherlands, July 20-24 (1998), Volume I: 637-646.

Yeo, D.C.J., Ng, P.K.L., Cumberlidge, N., Magalhaes, C., Daniels, S.R., Campos, M.R., 2008. Global diversity of crabs (Crustacea:Decapoda:Brachyura) in freshwater. Hydrobiologia 595: 275-286. http://dx.doi.org/10.1007/978-1-4020-8259-7 30 